\title{
Growth of Dunaliella in "Ideal" Conditions Retains Annual Variability of Biochemical Features
}

\author{
Anatoly I. Bozhkov", Natalia G. Menzyanova, Marina K. Kovaleva, Nikolai I. Pyatak \\ Research Institute of Biology, V.N. Karazin National University of Kharkov, 4, Svobody Sq., 61077 Kharkov, Ukraine \\ *Corresponding Author: bozhkov@univer.kharkov.ua
}

Copyright $@ 2014$ Horizon Research Publishing All rights reserved.

\begin{abstract}
In this work we investigated the annual dynamics of the biomass accumulation of microalgae Dunaliella viridis, its content of nucleic acids, proteins, and triacylglycerols at accumulative cultivation while maintaining the culture at "ideal constant conditions throughout the year in order to eliminate the high variability of these parameters, which occur in conventional culture conditions. The cultivation of $D$. viridis in constant conditions throughout the year had not eliminated the rhythmic nature of the biomass accumulation and pronounced variability of its composition. The variability has flicker noise structure with a period of about 4 months. This variability was not related with the seasons of the year, but in some cases coincided well with the dynamics of solar activity, in particular with the change of the corpuscular and electromagnetic radiation. Several types of interactions between biological indicators and solar activity were revealed: direct, inverse and U-shaped one. It was hypothesized the variably dominant factors explaining the diversity of responses to solar activity, which is based on a hierarchical organization of water-molecular structured network of cell.
\end{abstract}

Keywords Dunaliella viridis, lipids, $\beta$-carotene, Heliophysical Factors

\section{Introduction}

As is known, the functioning of biological systems is carried out in a rhythmic mode. Periodic change of activity (activities) manifests itself in the form of rhythms with various amplitude and frequency. All the variety of rhythms can be divided into exogenous $[23,25]$ and endogenous rhythms of nature $[7,8,26]$. Exogenous biorhythms are induced by changes in external factors influencing the activity of metabolic systems, it is, above all, a change of light and darkness, temperature, seasons and other endogenous biological rhythms induced feature of the temporal organization of metabolic and functional systems. It is clear, that a variety of endogenous and exogenous rhythms "stacked" on each other in a complicated manner unknown for us, which ultimately determines the temporal organization of biosystems.

It is a difficult task to investigate the temporal organization of the metabolism in the real world. However, without the knowledge and consideration of rhythmic activity of biosystems it is difficult to explain the high variability of often obtained results in the system in vivo and vitro; unstable efficiency of cellular systems in the biotech practice; the difficulties in establishing medical diagnoses, etc.

We are often faced with high variability of receiving $\beta$-carotene [21, 22], microbial biomass yield [10,24], and the ambiguity of the obtained scientific results.

As a rule, the experimenters are trying to "eliminate" really existing variability, which is a feature of the temporal organization of the biosystems.

For the 'elimination' of the functional variability of experimental data two approaches are used - a biological and mathematical. In the first case it is tried to form a genetically homogeneous sample of animals of the same age, sex, etc., or to use a relatively simple cell or cell-free systems, which are aimed to minimize the variability of the parameters studied. However, even these procedures do not eliminate flicker noise structure of time series [11,31].

The use of mathematical methods of experimental results analysis clearly eliminates "coming out" values, and it would seem to reduce the variability of experimental data, really eliminates the extreme variations in the time series but it is biologically incorrect. However, the study of the nature of flicker noise structure of time series is of great theoretical importance, since it reflects the dynamics of the adaptive responses of the organism. Besides the development of biological approaches to elimination of functional variability of metabolites or biomass receiving has great practical importance in particular in biotechnology.

In connection with this, we tried to create a "perfect" constant microalgae culture conditions in order to obtain a stable output of the biomass and its metabolites on the one hand and to estimate natural variability indices measured under these conditions.

It is known that the microalgae of genus Dunaliella are 
used to produce $\beta$-carotene, proteins and other metabolites $[12,17,32]$ and are model systems for studying of mechanisms of resistance to heavy metals $[2,18]$.

The main factors affecting the productivity of microalgae are: temperature, light, composition of the culture medium, the initial cell density $[13,16]$. To obtain a stable output of biomass and metabolites the "ideal" conditions for Dunaliella viridis were maintained throughout the year. Monthly in the early stationary phase of growth (21 days of culture) nucleic acids, proteins, triacylglycerols and $\beta$-carotene content were determined in the biomass of microalgae.

\section{Experimental Procedures}

The culture of one-cell microalgae Dunaliella viridis Teod. var. viridis f. euchlora, strain IBASU-A N 29 was used in experiments (collection of microalga cultures of M.G. Kholodny Institute of Botany, Kyiv, Ukraine).

\section{Culture conditions}

The microalgae were cultivated on the liquid Artary medium to modify Massjuk [28] in Erlenmeyer's $250 \mathrm{ml}$ flasks (volume of the cultural medium was $20 \mathrm{ml}$, initial cell concentration - 1,3 $\mathrm{mln} / \mathrm{ml}$ ) with twenty-four-hour illumination ( $4 \mathrm{klx}$ ), at constant temperature $26-28^{\circ} \mathrm{C}$.

Cell count was performed in a Goryaev-chamber. Cell concentration was expressed in million cells per $\mathrm{ml}$.

The determination of lipids and $\beta$-carotene contents

The $D$. viridis cells were precipitated by centrifugation for $20 \mathrm{~min}$ at $3000 \mathrm{~g}$ and were rinsed by medium two times. Lipids and pigments were extracted two times with organic solvents as early described [5].

The chlorophorm extracts were analyzed by thin-layer chromatography on the plates Kieselgel 60 (Merck, Germany) using hexan:diethyl ether (4:1). The quantity of lipids was determined using the method [5].The $\beta$-carotene was eluted by chloroform-methanol $(2: 1)$. The extinction of eluates was determined at $\lambda=400 \mathrm{~nm}$ using the spectrophotometer SF-46 (LOMO, Russia). The lipids and $\beta$-carotenes contents were relied on calibration curves and was expressed in $\mu \mathrm{g}$ per million of cells.

The determination of nucleic acids and protein contents

In the pellets after lipid extraction the of RNA and DNA were hydrolyzed as previously described [3]. After DNA and RNA hydrolysis the pellets were dissolved in $1 \mathrm{~N} \mathrm{NaOH}$ and the protein content was determined by Lowry method [20], the protein content was expressed in $\mu \mathrm{g}$ per million of cells.

The experiments were carried out from January to December of 1998. Each experiment was accomplished in 5 biological reiterations.

Data on solar activity (Wolf's number and the area of solar spots) were obtained on site www.spaceweather.com. The area value of solar spots was determined for each microalgae passage as a mean value for 21 days of cultivation.

\section{Results}

\subsection{Annual dynamics of accumulation of $D$. viridis cells at cultivation of at constant conditions of cultivation}

It is known that temperature, light and medium composition are the main factors determining the rate of cell proliferation. It is shown that in the accumulative cultivation under optimal conditions (temperature $26-28{ }^{\circ} \mathrm{C}$, illumination $4 \mathrm{klx}$, Artari standard medium), at an initial density of 1.3 million cell $/ \mathrm{ml}$ the $D$. viridis culture enters the stationary phase at the $18^{\text {st }}-21^{\text {rd }}$ day of growth (Fig. 1).

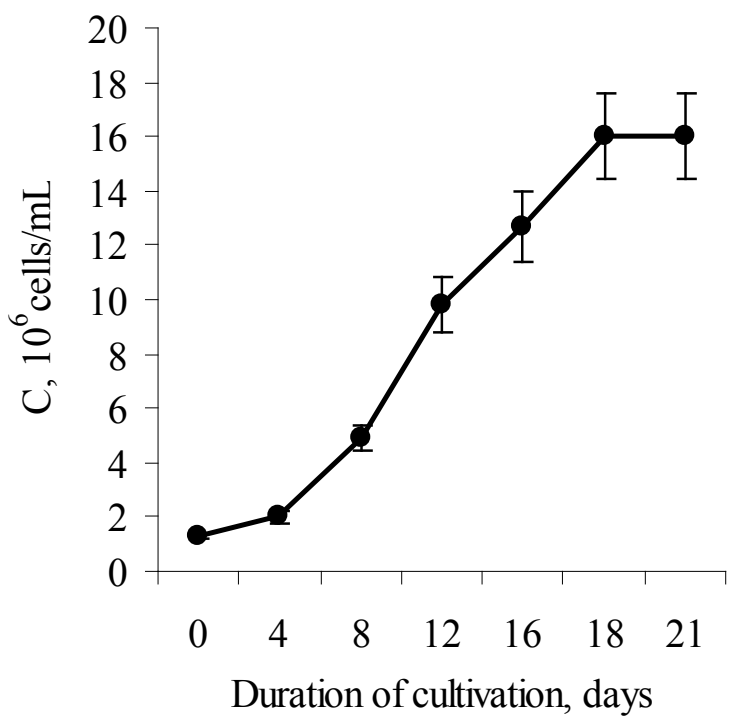

Figure 1. Growth dynamics of the microalgae D. viridis, C - cell concentration.

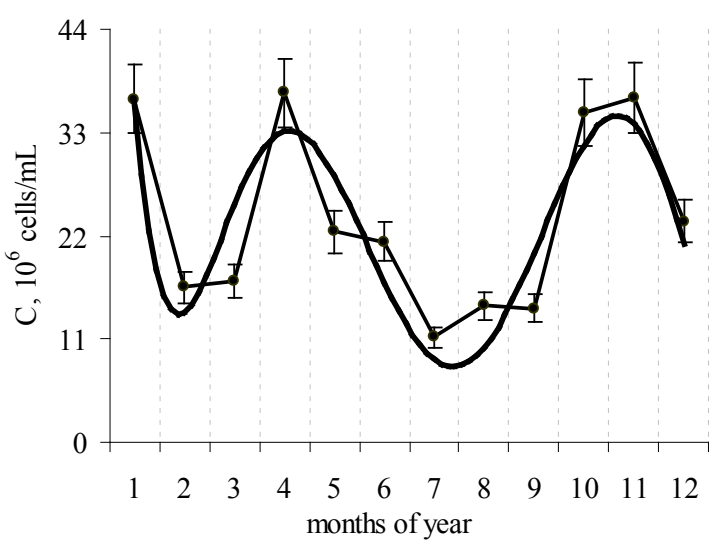

Figure 2. Cell concentration $\mathrm{C}$ in the 21-day culture $D$. viridis in various months in the course of the year (a) and within same passage (b) under standard cultivation conditions.

One may assume that, at the maintaining of the constancy of the optimal culture conditions throughout the year, each cycle of cultivation on the stationary phase of growth will provide the same output of cells.

The real experiment revealed completely different and unexpected patterns: 1) Under strictly constant, optimal for 
D. viridis culture conditions, the yield of cells on the $21^{\text {st }}$ day of growth ranged from $11-13 \mathrm{mln} / \mathrm{ml}$ to $28-30 \mathrm{mln} / \mathrm{ml}$ in different months of the year (Fig. 2).

2) Under strictly constant growth conditions the fluctuations in output for the cells of the same period of cultivation were quasi-periodic with a period of about 4 months. Quasi-periodic fluctuations in the rate of microalgae growth did not coincide with the seasonal cycles (Fig. 2).

3) Variability of cell yield on the $21^{\text {st }}$ day of accumulative cultivation in parallel biological repeats in different months of the year also wasn't the same. Cell population of $D$. viridis differently react to unknown or uncontrollable by experimenters factors in different months of the year (Fig. 2).

These results can be explained from two different positions.

1. In D. viridis, like a plant object, there are evolutionarily formed endogenous seasonal rhythms. In this case, the observed rhythms with a period of about 4 months have to coincide with changes in light and temperature. However, this is not the case.

2. The observed rhythms of the growth rate of the $D$. viridis are induced by unaccounted in the experiment fluctuations of global geoheliophysical factors such as solar activity.

Experimental cultures of microalgae were in a specially equipped room, isolated from the external environment, where the constant conditions (temperature, light, etc.) were maintained throughout the year. It can be assumed that corpuscular and electromagnetic components of solar radiation, which can easily penetrate to such spaces, can be the inducer of these quasi-periodic fluctuations of intensity of growth rate of microalgae. To evaluate the activity of the corpuscular and electromagnetic radiation Wolf number and area of sunspots were used. Imposition of the curves of yield of $D$. viridis cells at the $21^{\text {st }}$ day of accumulative cultivation under strictly constant conditions of cultivation during the year and the dynamics of average monthly Wolf number and area of sunspots over the same period is shown in Figure 3.

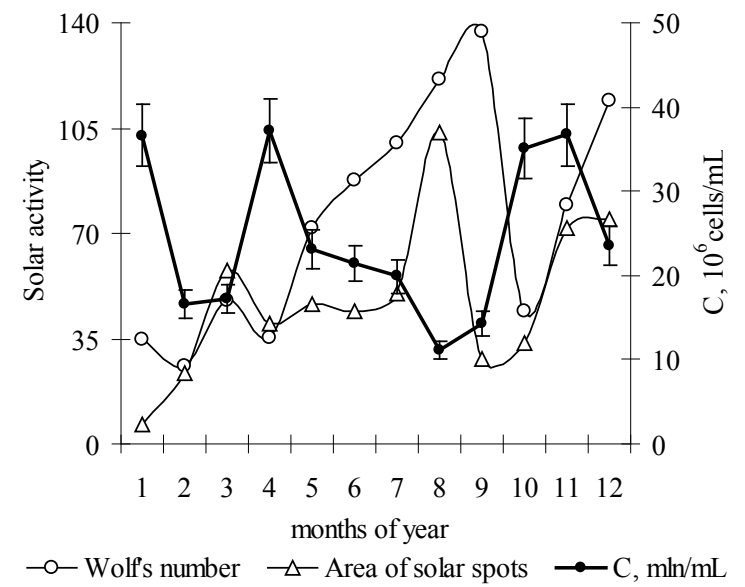

Figure 3. Cell concentration $\mathrm{C}$ in the 21-day culture D. viridis under standard cultivation conditions and fluctuations of Wolf's number and the area of solar spots $\left(\mathrm{Hemis}, \mathrm{x}^{-6}\right.$ ) in various months in the course of the year.
Decrease of the microalgae growth rate in the period from May to September occurred against a significant increase of the Wolf number and sunspot area. Conversely, a significant increase in cell yield in the $21^{\text {st }}$ day of cultivation in May, October, and November was observed at low solar activity (Fig. 3).

For a determination of "closeness" and the nature of the relationship between the studied parameters relationship between the output of the cells on the $21^{\text {st }}$ day of growth and the absolute values of the Wolf number and area of sunspots were analyzed. It has been found that there is an inverse relationship (the degree of approximation accuracy $\mathrm{R}^{2}=0,76$ ) between the absolute values of the Wolf number and cell number in 21-day-old culture (Fig. 4a). Moreover, this dependence is exponential. Thus, an increase in the Wolf number from 35 to 70 was accompanied by a sharp, almost linear decrease in the number of algae cells. In the interval 70 - 140 units output of cells did not change significantly. It is important to note the different reactions of the cell population of microalgae to different ranges of solar activity.

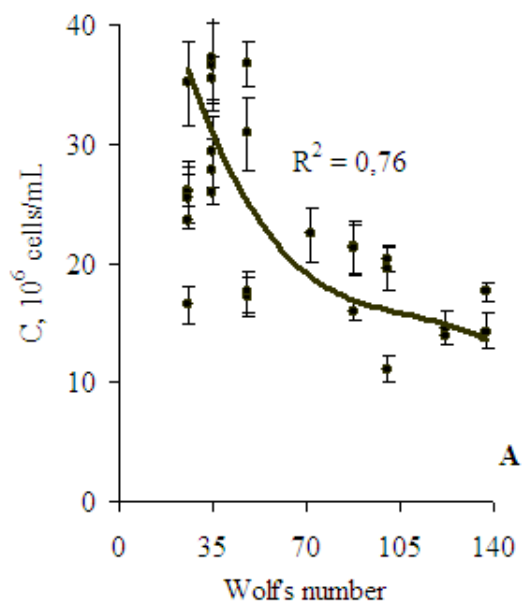

A

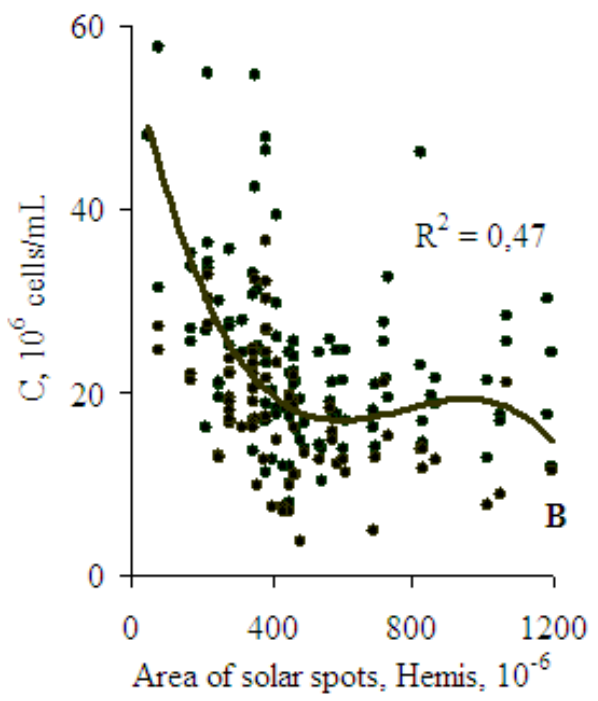

Figure 4. Dependence of the cell concentration $\mathrm{C}$ in the 21-day culture $D$. viridis on the absolute values of Wolf's number (a) and the area of solar spots (Hemis, $\left.\times 10^{-6}\right)(b)$. 
The trend line on Fig. 4a is built with polynomial approximation (degree 3), on Fig. $4 \mathrm{~b}$ the trend line is built with polynomial approximation (degree 4). For each trend line the approximation accuracy $\left(R^{2}\right)$ is specified

It should be noted that there were experiments with large number of biological repeats in (number of flasks with microalgae cultured simultaneously reached 30 ). This revealed a very high dispersion of cell yield in 21-day-old cultures (Fig. 4a). A high level of dispersion indicates that the initial responses of microalgae cell population to the same fluctuations of solar activity may vary significantly. That is, the population of algae is characterized by heterogeneity of the intensity of the response to fluctuations in solar activity.

This nonlinear dependence is detected also between output of cells in 21-day-old culture and the sunspots area, but the reliability of the approximation in the case is $\mathrm{R}^{2}=0,47$ (significantly lower than for the Wolf number) (Fig. 4b). Consequently, the increase in the absolute values of the Wolf number (range 35 - 70 units) and the area of sunspots (50 $400 \mathrm{Hemis}, \mathrm{x} 10^{-6}$ ) was accompanied by a sharp decrease in cell yield in the 21-day-old culture of $D$. viridis. A further increase in the values of indicators of solar activity had no significant effect on the yield of microalgae cells in 21-day-old culture. The "parallel" biological repeats of cell cultures differed significantly in magnitude of responses to changes in the parameters of solar activity.

In the next phase of work the dynamics of the content of the primary metabolite exchange (RNA, protein) and secondary metabolism (triacylglycerols (TAG), and B-carotene) $D$. viridis was determined when cultured under standard conditions during the year.

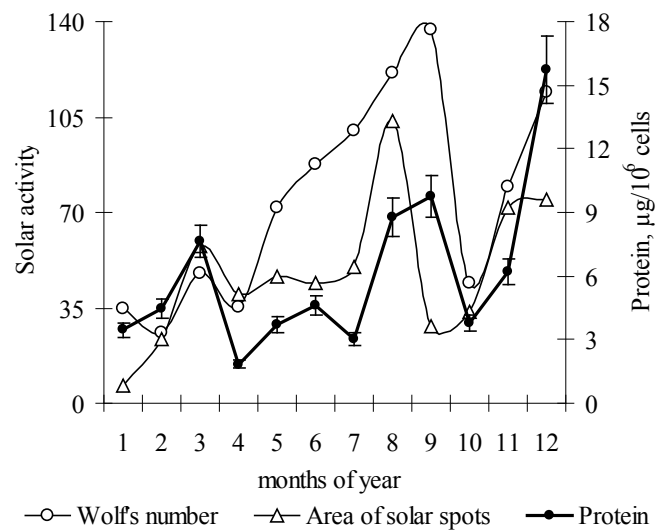

Figure 5. The protein content $\left(\mu \mathrm{g} / 10^{6}\right.$ cells) in cells of 21 -day culture $D$. viridis under standard cultivation conditions and fluctuations of Wolf's number and the solar spots area $\mathrm{S}\left(\mathrm{Hemis}, \mathrm{x} 10^{-6}\right.$ ) in various months in the course of the year.

\subsection{Annual rhythm of indicators of primary exchange (content of RNA and protein) in the cells of $D$. viridis at constant cultivation conditions throughout the year}

The protein content was determined in cell biomass of $D$. viridis in different months of the year on the $21^{\text {st }}$ day of growth with constant conditions of cultivation (Fig. 5). This measure also varied rhythmically:

- $\quad$ the first cycle: January - April;

- $\quad$ the second, less pronounced cycle: April - July;

- $\quad$ the third marked cycle: June - October;

- a sharp increase in the protein content from October to December.

Consequently, over the years the quasi-periodic fluctuations in the protein content in the $D$. viridis cells with a period of about 4 months were revealed. Annual protein dynamics in cells did not coincide with the dynamics of the output of cells in 21-day-old culture (Fig. 3, 5).

If we impose the curve of protein content in the algae cells and dynamics of monthly mean values of solar activity, certain patterns are identified. Thus, an increase in solar activity in March, August, September and December coincided with increased protein content in the cells of $D$. viridis. Against the background of low solar activity, the protein content in the cells decreased (Fig. 5).

It should be noted the variability in the content of protein in microalgae cells. The protein content varied during the year from $1.8 \mu \mathrm{g} /$ million cells (April) to $15.7 \mu \mathrm{g} /$ million cells (December), the difference in the content by 8.7 times. The variability of cells output in 21-day-old culture during the year was less pronounced. Consequently, the degree of variability of the molecular parameters for a year is significantly higher than the variability of the cell number in the same culture conditions.

The coefficients of reliability of approximation and the character of correlative relations between the absolute values of the indicators of solar activity and the protein content in the cells of 21-day-old cultures of $D$. viridis suggested high variability and ambiguity of a biological response at the molecular level.

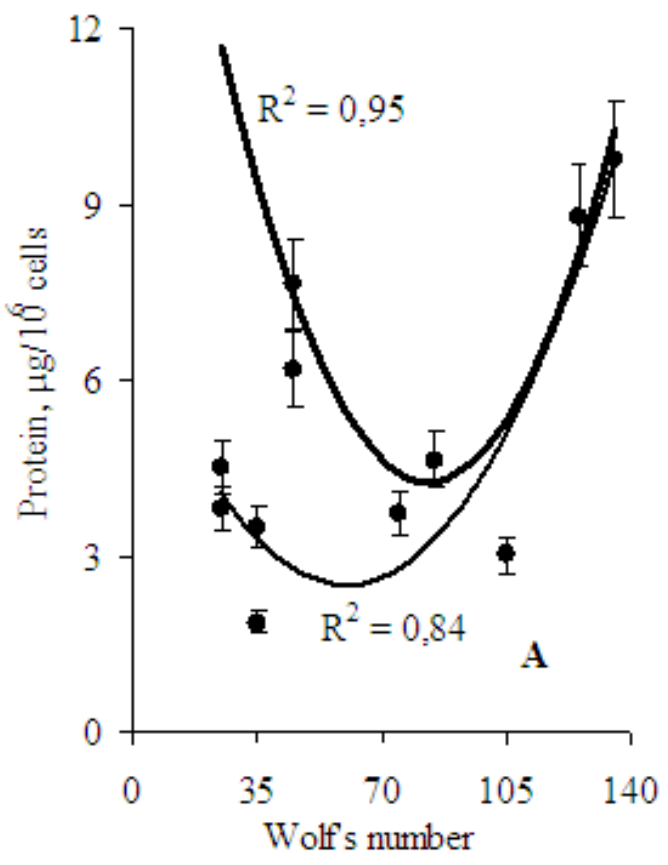




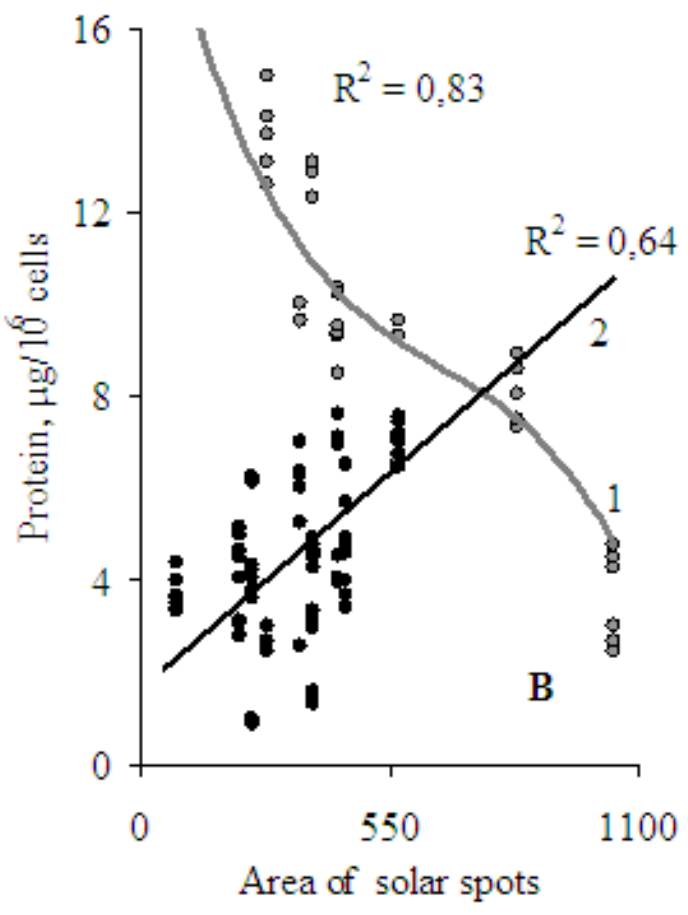

Figure 6. Dependence of the protein content in cells of the 21-day-old culture $D$. viridis on the absolute values of Wolf's number (a) and the solar spots area $\left(\mathrm{Hemis}_{\mathrm{s}} \times 10^{-6}\right)(\mathrm{b})$.

On the Fig. 6a the upper and lower trend lines were built with polynomial approximation (degree 2), on the Fig. $6 \mathrm{~b}$ the grey trend line (1) is built with polynomial approximation (degree 3), the black trend line (2) is built with linear approximation. For each trend line the approximation accuracy $\left(\mathrm{R}^{2}\right)$ is specified.

Thus, between the absolute value of Wolf number and protein content in the cells of $\mathrm{D}$. viridis a complex U-shaped relationship was revealed (Fig. 6a).

In this case, the two relatively discrete groups (two variants of the cellular response) with high coefficients of reliability of the approximations of the trend lines were forming in data set (Fig. 6a).

The complicated relationship was detected between the sunspots area and protein content in the cells of $D$. viridis (Fig. 6b). There were two relatively discrete groups of biological responses in the array of data also. For one group of data protein decreased with increasing area of sunspots (coefficient of reliability of approximation $\mathrm{R}^{2}=0,83$ ). For the second group of data the protein content increased linearly with the increase in the area of sunspots (coefficient of reliability of approximation $\mathrm{R}^{2}=0,64$ ) (Fig. $6 \mathrm{~b}$ ).

RNA content in the $D$. viridis cells of 21-day-old culture rhythmically varied during the year (a period of about 4 months) (Fig. 7a).

The imposition of the dynamics of average monthly values of the indicators of solar activity and the dynamics of the RNA content revealed the periods when an increase in solar activity is accompanied by an increase in RNA content in microalgae cells. But relation between the rhythm of the solar activity and content of RNA in cells, as it was found for cellular protein was not observed (Fig. 7b).
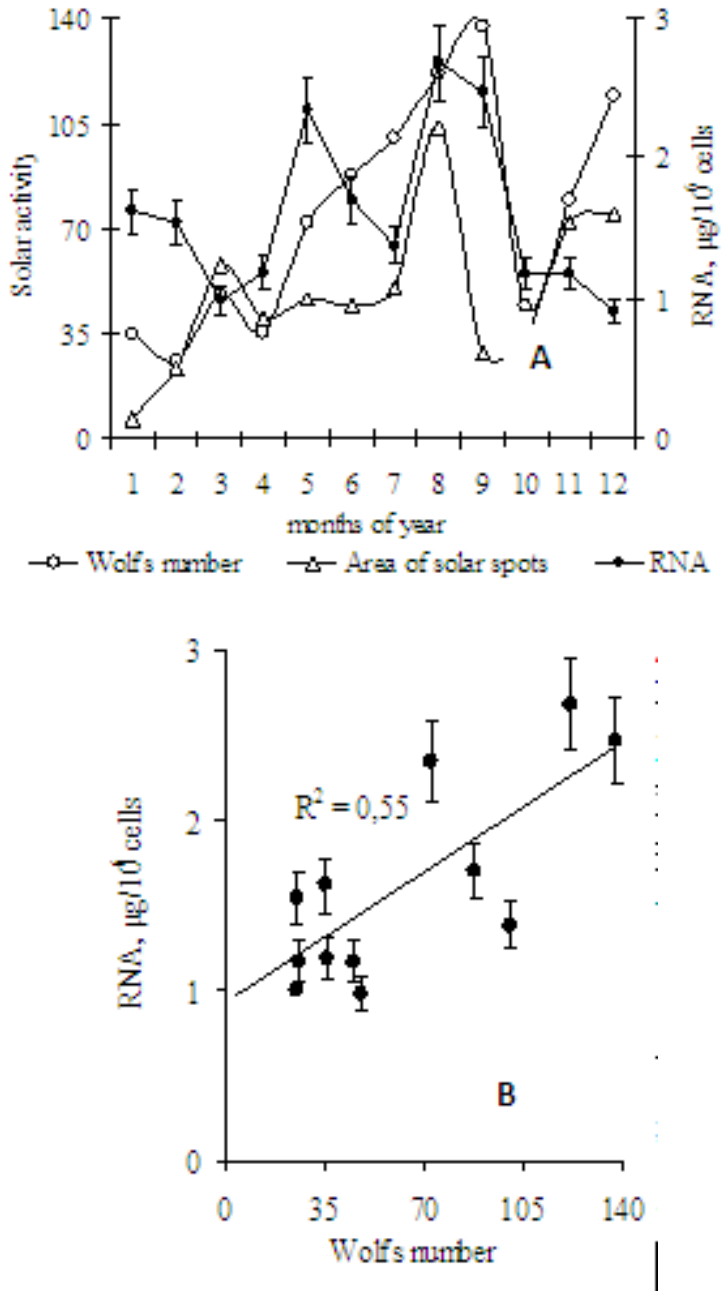

Figure 7. The RNA content ( $\mu \mathrm{g} / 10^{6}$ cells) in cells of 21-day culture $D$. viridis under standard cultivation conditions and fluctuations of Wolf's number and the solar spots area $\mathrm{S}\left(\mathrm{Hemis}, \mathrm{x} 10^{-6}\right)$ in various months in the course of the year (a); dependence of the RNA content in cells of the 21-day culture $D$. viridis on the absolute values of Wolf's number (b).

The trend line on the Fig. $7 \mathrm{~b}$ is built with linear approximation. The accuracy of approximation $\left(R^{2}\right)$ is specified for trend line.

\subsection{The annual rhythm of secondary metabolic parameters (content of TAG and B-carotene) in the cells of $D$. viridis at constant cultivation conditions throughout the year}

TAG content in the cells of 21-day-old cultures of $D$. viridis under constant conditions rhythmically changed throughout the year (Fig. 8).

This rhythm has flicker-noise character. It should be noted that the fluctuations of solar activity coincided with the fluctuations of the TAG content in cells throughout the year (Fig.8): periods of low-TAG content in the cells coincided with periods of low solar activity in January-February and September-October. For the period of June-July, with the highest level of solar activity there was the highest content of TAG in the cells of $D$. viridis. The maximum and minimum 
content of TAG in the cells of algae on the $21^{\text {st }}$ day of growth differed 3-fold (Fig.8).

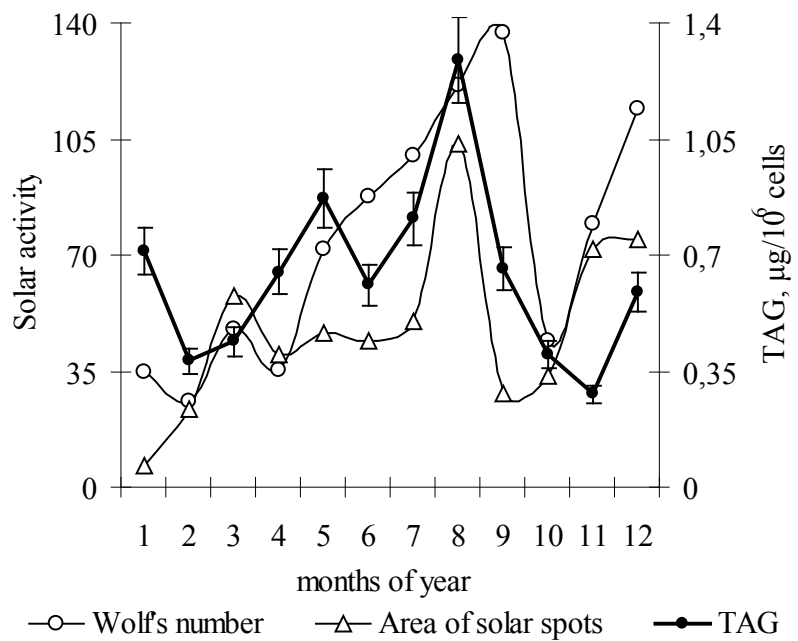

Figure 8. The triacylglyceride content (TAG, $\mu \mathrm{g} / 10^{6}$ cells) in cells of 21-day culture $D$. viridis under standard cultivation conditions and fluctuations of Wolf's number and the solar spots area $\mathrm{S}\left(\mathrm{Hemis}, \mathrm{x} 10^{-6}\right)$ in various months in the course of the year.

There was no expressed relationship between the absolute values of the Wolf number and the content of TAG (coefficient of reliability of approximation $\mathrm{R}^{2}=0.37$ ) (Fig. 9a).

To a much greater extent the content of TAG in microalgae cells depended on the area of sunspots. As in the case of protein content it was U-shaped dependence (Fig. $9 b)$.

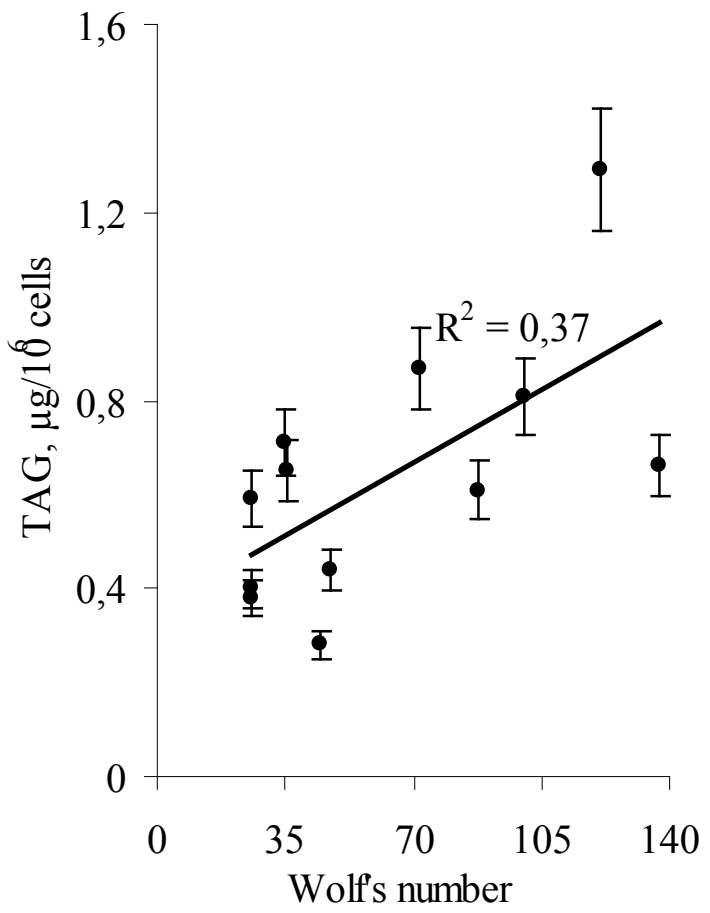

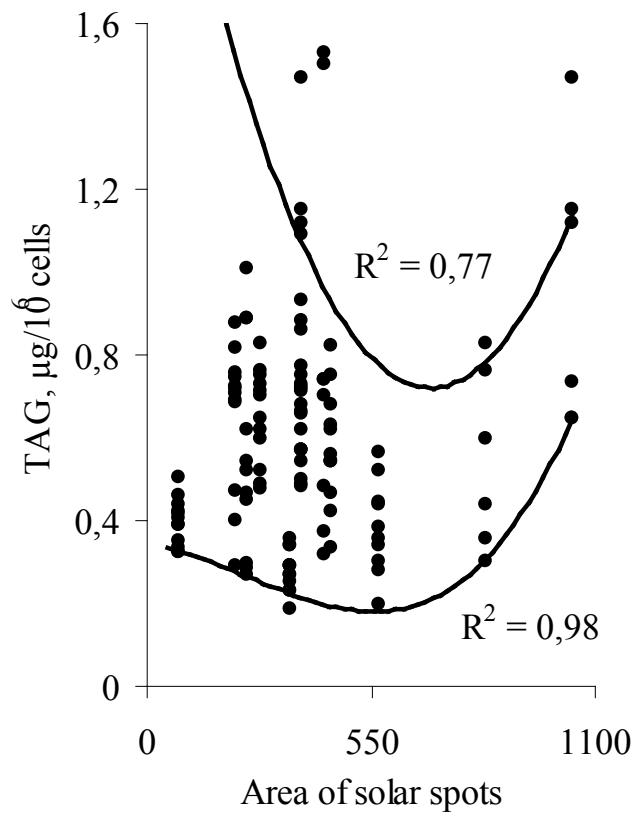

Figure 9. Dependence of the of triacylglyceride content (TAG) in cells in the 21-day culture $D$. viridis on the absolute values of Wolf's number (a) and the area of solar spots (Hemis, $\left.\times 10^{-6}\right)(b)$.

On the Fig. 9a the trend line is built with linear approximation, on the Fig. 9b the upper and lower trend lines were built with polynomial approximation (degree 2 and 3). For each trend line the approximation accuracy $\left(\mathrm{R}^{2}\right)$ is specified.

It was found that $\beta$-carotene content changed rhythmically and these changes not coincided with monthly changes of Wolf's number and sunspot square (Fig. 10a).

However the comparison of absolute values of Wolf's number and $\beta$-carotene content showed the $U$-shape relation between them (Fig. 10b). A wide corridor of variability of $\beta$-carotene content can be explained by influence of different local factors on carotenogenesis.

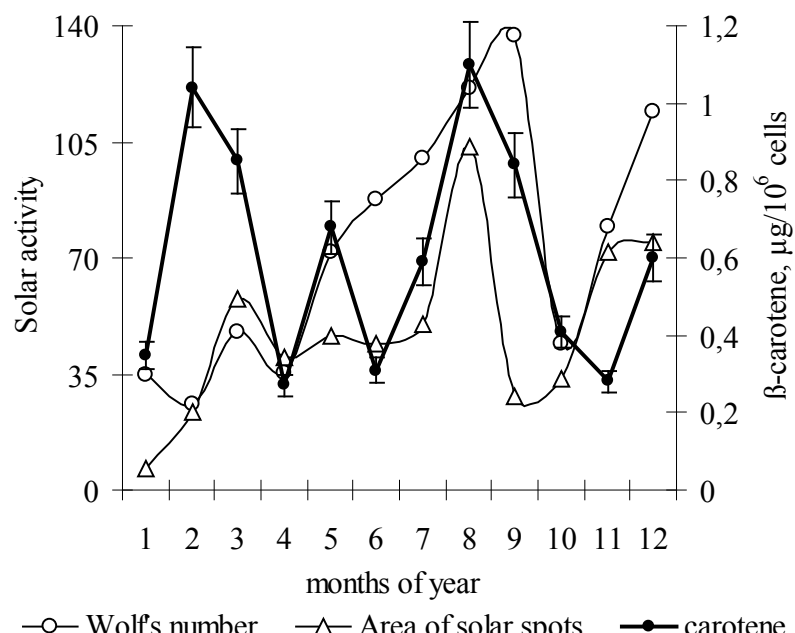




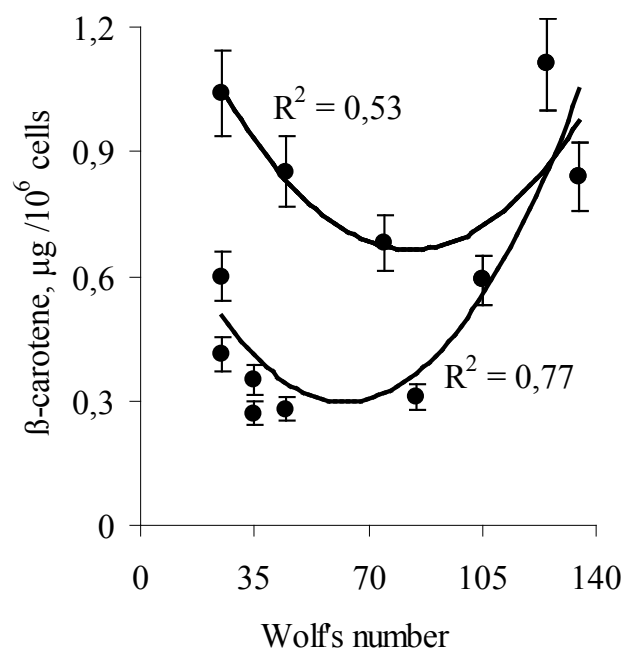

Figure 10. The $\beta$-carotene content $\left(\mu \mathrm{g} / 10^{6}\right.$ cells) in cells of 21-day culture $D$. viridis under standard cultivation conditions and fluctuations of Wolf's number and the solar spots area $\mathrm{S}\left(\mathrm{Hemis}, \times 10^{-6}\right)$ in various months in the course of the year (a); dependence of the $\beta$-carotene content in cells of the 21-day culture Dunaliella viridis on the absolute values of Wolf's number (b).

On the Fig. 10b the upper and lower trend lines were built with polynomial approximation (degree 2). For each trend line the accuracy of approximation $\left(\mathrm{R}^{2}\right)$ is specified.

\section{Discussion}

The cultivation of microalgae D. viridis in "ideal" conditions for the species, constant throughout the experimental period of the year, did not eliminate the rhythmic nature of the biomass accumulation and high variability of its composition.

Identified variability biomass yield and composition had flicker noise structure with a period of about 4 months. This frequency was not related with the seasons of the year, but in some cases coincided well with the dynamics of solar activity, in particular with changes in particle radiation (Wolf number) and electromagnetic radiation (the area of sunspots).

In some cases there was strong relationship between the biological parameters and the absolute values of the Wolf number and area of sunspots (the accuracy of the approximation reached 0,8-0,9). For other biological parameters dependence on the absolute values heliophysical factors was less pronounced (the accuracy of the approximation was $0,4-0,6$ ).

The main types of relationships between biological indicators and solar activity can be divided in three groups: direct, inverse and U-shaped. Moreover, in some cases a single data array can be divided into two discrete groups of microalgae, differed by the response to fluctuation of solar activity.

These results suggested some general assumptions.

1. The pacemaker of identified rhythm or variability of biochemical parameters $D$. viridis is corpuscular and electromagnetic components of solar radiation.

2. The biological systems respond differently to different ranges of solar radiation., i.e., there are "open", "closed" and "neutral" for $D$. viridis bands of the electromagnetic and corpuscular radiation.

3. Responses of biological systems to fluctuations in solar activity can depend on properties of the biological objects not controlled by us: the prehistory of the object features of a functional state at the time of exposure and so on.

The content of these assumptions is resulted to an understanding of the ambiguity of the "interaction" of the electromagnetic and corpuscular radiation with biological objects and features of the mechanisms of formation of the responses that we are able to assess experimentally.

We have hypothesized variably dominant factors (VDF), which can explain the formation of the ambiguity of the biological response to fluctuations of heliophysical factors and possibly to other environmental factors [4].

The content of this hypothesis is the following. The cell as a dynamic system of biopolymers, small molecules, a variety of ions and molecules of water can receive and generate electromagnetic waves of different range [6, 19, 33]. Molecular organization of the cell can be represented not only as a spatial-temporal compartmentalization, but also as a hierarchically organized water-molecular structured network (WMSN), which elements vary by size, energetic capacity, the ability to accumulate energy and spatial movement.

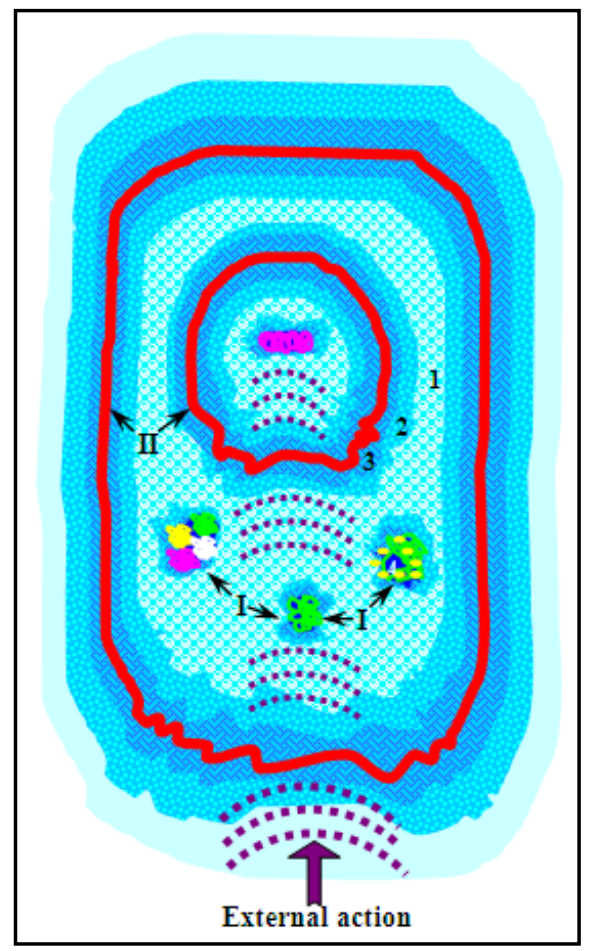

Figure 11. The scheme of water-molecular-structured cell network. Water molecules form several aqueous "shells" around the macromolecules (I) and cell structures (II). These aqueous "shells" are differed by the degree of strength of the intermolecular bonds. 
For WMSN elementary or basic level is the water molecule. This WMSN may have a number of properties. First of all, for WMSN there should be different thresholds for "accumulation" or "concentration" of the energy of electromagnetic radiation, depending on its level of organization (hierarchy). The energy after reaching critical threshold, from a basic level energy can be transferred to the next level of the hierarchy structure - to supramolecular and forth - the cellular level (Fig. 11).

The "behavior" of the water molecules, which are located near the hydrophobic or hydrophilic regions of macromolecules gives the evidence of the existence of WMSN in the cell. Halle (2004) proposed to distinguish the water contained within the hydrophilic regions of the protein molecules. Such water is present in most, and perhaps all globular protein and is an integral part of the structural proteins $[14,27]$.

It was shown that near the biological surfaces (proteins, membranes, etc.) in water the intermolecular rearrangement of the hydrogen bonds occur, leading to ordering of water molecules [9]. It is shown that such "orderly" water has changed properties: reduced mobility of the molecules [1, 29], the dielectric constant [30], and the viscosity [34].

The water molecules can form several layers of water on the surface of biological membranes in the interaction with specific chemical groups of the lipid [15].

These results suggested a possible base role of water in the forming of WMSN of cells. Considered the extremely high dynamics of weak intermolecular bonds, we can understand the high heterogeneity of responses of biological systems to the weak and super-weak electromagnetic influences.

One may assume that the critical levels of energy "accumulation" can provide synchronization and regulation of the molecular processes leading to the formation of a relatively narrow channel of responses to a wide range of exogenous influences.

The ability of cells to generate electromagnetic waves, and at the same time to be the receiver of the external electromagnetic oscillations can explain the multivariate response of biological systems to the same external influences on the one hand, and the uniformity of the responses of biological systems to a variety of influences.

Features of the "interaction" or "interference" of endogenous and exogenous electromagnetic fields have not been studied, but it is they who provide the formation of the response of the biosystem. One can assume that these features can be reduced to a few variants:

1. to the dominance of "endogenous" fields;

2. to the dominance of "exogenous" fields;

3. to the formation of new electromagnetic characteristics of the WMSN of cells.

According to the dynamics of response change and variability of biological responses at different times of the year, we can assume that there is an alternating dominance of endogenous and exogenous factors (endogenous and exogenous electromagnetic fields) which determine the biological response.
It can be assumed that the nature of dominance will be affected by not only and not so much the absolute value of the external (exogenous) factors, but also by the rate of change of their endogenous and exogenous fields, i.e., by the rate of change of parameters.

Consequently, the initial state of WMSN in certain ranges will determine the subsequent cellular response to exogenous impacts. This may explain the multivariate responses of biological systems and different sensitivity to external influences.

\section{REFERENCES}

[1] S. Balasubramanian, S. Pal, B. Bagchi. Hydrogen-bond dynamics near a micellar surface: Origin of the universal slow relaxation at complex aqueous interfaces PACS, Physical Review Letters, Vol. 89, 115505, 2002.R. F. Voss, J. Clarke. Algorithmic Musical Composition, Silver Burdett Press, Londyn, 1986.

[2] A.I. Bozhkov, N.G. Menzyanova, K.V. Sedova, A.V. Goltvyanskiy. The influence of high temperature on cells of Dunaliella viridis (Teod.) (Chlorophyta) sensitive and resistant to copper ions, International Journal on Algae, Vol. 13, No.3, 203-222, 2011.

[3] A.I. Bozhkov, M.K. Kovaleva, N.G. Menzianova. Is it possible to "cancel" aging process of cell cultures under optimal conditions for cultivation?, Advances in Gerontolology, Vol. 24, No.1, 26-37, 2011.

[4] A.I. Bozhkov, N.G. Menzyanova, M.K. Kovaleva. Annual rhythm of growth intensity of microalgal culture Dunaliella viridis Teod. (Chlorophyta) and fluctuations of some heliophysical factors, International Journal on Algae, Vol. 10, No.4, 350-364, 2008.

[5] A.I. Bozhkov, N. G. Menzyanova. Growth dynamics, lipid composition, and ( $\beta$-carotene content in cells of Dunaliella viridis Teod. under cultivation in different types of photobioreactors, International Journal on Algae, Vol. 1, No.3, 31-39, 1999.

[6] L. Brizhik. Nonlinear mechanism for weak photon emission from biosystems, Indian Journal of Experimental Biololy, Vol. 46, No.5, 353-357, 2008.

[7] V.Y. Brodsky, N.D. Zvezdina. Melatonin as the most effective organizer of the rhythm of protein synthesis in hepatocytes in vitro and in vivo, Cell Biology International, Vol. 34,No.12, 1199-1204, 2010.

[8] V.Y. Brodsky, N.D. Zvezdina, V.I. Fateeva, L.A. Malchenko. Involvement of protein kinases in self-organization of the rhythm of protein synthesis by direct cell-cell communication, Cell Biology International, Vol. 31, No.1, 65-73, 2007.

[9] Y.K. Cheng, P.J. Rossky. Surface topography dependence of biomolecular hydrophobic hydration, Nature, Vol. 392, No.6677, 696-699, 1998.

[10] C.C. Cunha, J. Glassey, G.A. Montague, S. Albert, P. Mohan. An assessment of seed quality and its influence on 
productivity estimation in an industrial antibiotic fermentation, Biotechnology and Bioengineering, Vol. 78, No.6, 658-69, 2002.

[11] K. Fisch, T. Schwalger, B. Lindner, A.V. Herz, J. Benda. Channel noise from both slow adaptation currents and fast currents is required to explain spike-response variability in a sensory neuron, Journal of Neuroscience, Vol. 32, No.48, 17332-17344, 2012.

[12] M. Francavilla, P. Trotta, R. Luque. Phytosterols from Dunaliella tertiolecta and Dunaliella salina: a potentially novel industrial application, Bioresource Technology, Vol. 101, No.11, 4144-4150, 2010.

[13] W. Fu, O. Guðmundsson, G. Paglia, G. Herjólfsson, O.S. Andrésson, B.O. Palsson, S. Brynjólfsson. Enhancement of carotenoid biosynthesis in the green microalga Dunaliella salina with light-emitting diodes and adaptive laboratory evolution, Applied Microbiology and Biotechnology, Vol. 97, No.6, 2395-2403, 2013.

[14] B. Halle. Protein hydration dynamics in solution: a critical survey, Philosophical Transactions of Royal Society Lond. Ser. B., Vol. 359, No. 1448, 1207-1224, 2004.

[15] M.J. Higgins, M. Polcik, T. Fukuma, J.E. Sader, Y. Nakayama, S.P. Jarvis. Structured water layers adjacent to biological membranes, Biophysical Journal, Vol. 91, No.7, 2532-2542, 2006.

[16] W. Kim, J.M. Park, G.H. Gim, S.H Jeong., C.M. Kang, D.J. Kim, et al. Optimization of culture conditions and comparison of biomass productivity of three green algae, Bioprocess and Biosystems Engineering, Vol. 35, No.1-2, 19-27, 2012.

[17] P.P. Lamers, M. Janssen, R.C. De Vos, R.J. Bino, R.H. Wijffels, Carotenoid and fatty acid metabolism in nitrogen-starved Dunaliella salina, a unicellular green microalga, Journal of Biotechnolology, Vol. 162, No.1, 21-27, 2012.

[18] J.L. Levy, B.M. Angel, J.L. Stauber, W.L. Poon, S.L. Simpson, S.H. Cheng et al. Uptake and internalisation of copper by three marine microalgae: comparison of copper-sensitive and copper-tolerant species, Aquatic Toxicology, Vol. 89, No.2, 82-93, 2008.

[19] A.R. Liboff. Electric polarization and the viability of living systems: ion cyclotron resonance-like interactions, Electromagnetic Biology and Medicine, Vol. 28, No.2, 124-134, 2009.

[20] O.H. Lowry, N.J. Rosebrough, A.L. Farr, R.J. Randall. Protein measurement with the Folin phenol reagent, Journal of Biological Chemistry, Vol. 193, 265-275, 1951.

[21] N.G. Menzyanova, A.V. Goltvyansky, Y.A. Kuznetsova, E.I. Sisenko. Season variability of iron effects on periodic culture of microalgae Dunaliella viridis Teod., Frontier of Biology in China, Vol. 4, No.3, 328-336, 2009.

[22] N.G. Menzyanova. The growth intensity and composition of biomass in the batch culture of Dunaliella viridis Teod. (Chlorophyta), Algologia, Vol. 12, No.1, 59-68 (in Russian), 2002.

[23] S. Monecke, D. Sage-Ciocca, F. Wollnik, P. Pévet. Photoperiod can entrain circannual rhythms in pinealectomized European hamsters, Journal of Biological Rhythms, Vol. 28, No.4, 278-290, 2013.

[24] A.A. Neves, L.M. Vieira, J.C. Menezes. Effects of preculture variability on clavulanic acid fermentation, Biotechnology and Bioengineering, Vol. 72, No.6, 628-633, 2001.

[25] N. Pagon, S. Grignolio, A. Pipia, P. Bongi, C. Bertolucci, M. Apollonio. Seasonal variation of activity patterns in roe deer in a temperate forested area, Chronobiology International, Vol. 30, No.6, 772-785, 2013.

[26] W. Pierpaoli. Cancer and the endogenous "pineal clock": a means of early diagnosis and successful treatment as well as prevention of cancers, Current Aging Science, Vol. 6, No.1, 108-114, 2013.

[27] S. Park, J. G. Saven. Statistical and molecular dynamics studies of buried waters in globular proteins. Proteins Structure Function and Bioinformatics, Vol. 60, No.3, 450-463, 2005.

[28] Yu. I. Posudin, N.P. Massjuk, G.G. Lilitskaya. Effect of ultraviolet radiation on photomovement of two species of Dunaliella Teod., International Jounal on Algae, Vol. 6, No.1, 61-73, 2004.

[29] D. Russo, G. Hura, T. Head-Gordon. Hydration dynamics near a model protein surface, Biophysical Journal, Vol. 86, No.3, 1852-1862, 2004.

[30] J.M. Shaw, G.M. Jones. Terminology associated with vitrification and other cryopreservation procedures for oocytes and embryos, Human Reproduction Update, Vol. 9, No.6, 583-605, 2003.

[31] J. Stewart-Ornstein, J.S. Weissman, H. El-Samad. Cellular noise regulons underlie fluctuations in Saccharomyces cerevisiae, Molecular Cell, Vol. 45, No.4, 483-493, 2012.

[32] Z.W. Ye, J.G. Jiang, G.H. Wu. Biosynthesis and regulation of carotenoids in Dunaliella: progresses and prospects, Biotechnolology Advances, Vol. 26, No.4, 352-360, 2008.

[33] M. Zhadin, L. Giuliani. Some problems in modern bioelectromagnetics, Electromagnetic Biology and Medicine, Vol. 225, No.4, 227-243, 2006.

[34] Y. Zhu, S. Granick, Viscosity of interfacial water, Physical Review Letters, Vol. 87, No.9, 096-105, 2001. 